\title{
Novel Organic Sensitizers with a Quinoline Unit for Efficient Dye-sensitized Solar Cells
}

\section{Hyeju Choi, Hyunbong Choi, Sanghyun Paek, Kihyung Song, ${ }^{\dagger}$ Moon-sung Kang, ${ }^{\dagger}$ and Jaejung Ko ${ }^{*}$}

\author{
Department of Advanced Material Chemistry, Korea University, Jochiwon, Chungnam 339-700, Korea \\ ${ }^{*}$ E-mail:jko@korea.ac.kr
}

†Department of Chemical Education, Korea National University of Education, Cheongwon, Chungbuk 363-791, Korea

${ }^{*}$ Energy Lab, Samsung SDI Corporate R\&D Center, Yongin, Gyeonggi-do 449-577, Korea

Received September 30, 2009, Accepted December 4, 2009

\begin{abstract}
Three organic sensitizers, JK-128, JK-129, and JK-130 containing quinoline unit are designed and synthesized. Under standard global AM 1.5 solar condition, the JK-130 sensitized solar cell gave a short circuit photocurrent density of $11.52 \mathrm{~mA} \mathrm{~cm}^{-2}$, an open circuit voltage of $0.70 \mathrm{~V}$, and a fill factor of 0.75 , corresponding to an overall conversion efficiency of $6.07 \%$. We found that the $\eta$ of $\mathbf{J K}-\mathbf{1 3 0}$ was higher than those of other two cells due to the higher photocurrent. The higher $J_{\mathrm{sc}}$ value is attributed to the broad and intense absorption spectrum of JK-130.
\end{abstract}

Key Words: Quinoline, Dye, Bithiophene, Dye-sensitized solar cell

\section{Introduction}

Increasing energy demands and environmental issues such as fossil fuel shortage and global warming have lead to the need for clean renewable energy. ${ }^{1}$ Dye-sensitized solar cells are attracting widespread interest for a renewable energy source as a cost-effective alternative to conventional solid-state solar cells. ${ }^{2}$ In this cell, the sensitizer is a crucial element in DSSCs, exerting significant influence on the power conversion efficiency as well as the stability of the devices. Some polypyridyl ruthenium sensitizers have reached power conversion efficiencies over $11 \%{ }^{3}$ Due to their precious metal and limited quantity, cheap metal-free organic sensitizers need to be developed for commercial applications. Recently impressive photovoltaic performance has been obtained with some organic indoline ${ }^{4}$ and triarylamine dyes ${ }^{5}$ having efficiencies in the range of $8 \sim 9.7 \%$. The efficient organic dyes contained a donor and acceptor moiety bridged by $\pi$-conjugation. In order to improve the photovoltaic performance and stability of DSSCs, an important strategy on organic sensitizers has been the structural modification of the compounds. The absorption spectra of organic sensitizers have to be red-shifted and broadened by expansion of the $\pi$-conjugation in the dyes. To obtain organic sensitizers with both redshift absorption and high stability, introduction of new $\pi$-conjugation units into organic framework is necessary.
Recently, a successful approach was introduced by incorporating a $\pi$-conjugation linker such as thiophene, ${ }^{6}$ thienothiophene, ${ }^{7}$ 3,4-ethylenedioxy-thiophene, ${ }^{8}$ benzo[1,2,5]-thiadiazole $^{9}$ and $p$-phenylene vinylene derivatives. ${ }^{10}$ As part of our efforts to investigate the structural modifications that can enhance the efficiency and stability, organic dyes containing quinoline moiety have been synthesized for DSSCs (Fig. 1).

It is well documentated that molecules and polymers containing quinoxaline, ${ }^{11}$ oxidiazole,${ }^{12}$ and quinoline ${ }^{13}$ offer highly efficient electron-transport material. Jenekle and co-workers ${ }^{14}$ reported that a new n-type conjugated copolymer containing 3,3'-dialkylthiophene and bis(phenylquinoline) moiety was shown to be a good electron-transport material. One challenge is to develop more efficient and robust electron-transport organic sensitizers which can be utilized as an efficient dye-sensitized solar cell. In this paper, we report three organic dyes containing quinoline as bridged group. We also investigated the effect of bridged structural modifications on the power conversion efficiency.

\section{Results and Discussion}

The novel organic sensitizers JK-128, JK-129, and JK-130 were prepared by the synthetic protocol depicted in Scheme 1. 1-(4-(Bis(9,9-dimethyl-9H-fluoren-2-yl)amino)phenyl)ethan-

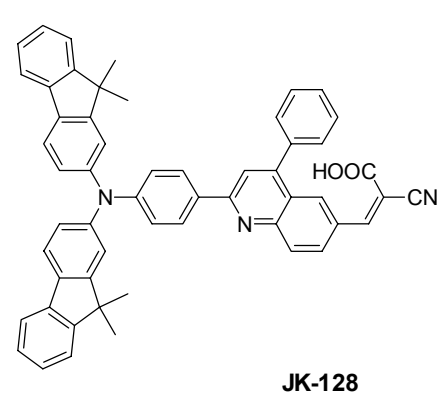

JK-128

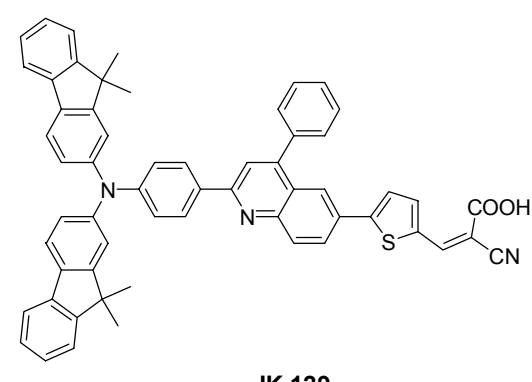

JK-129

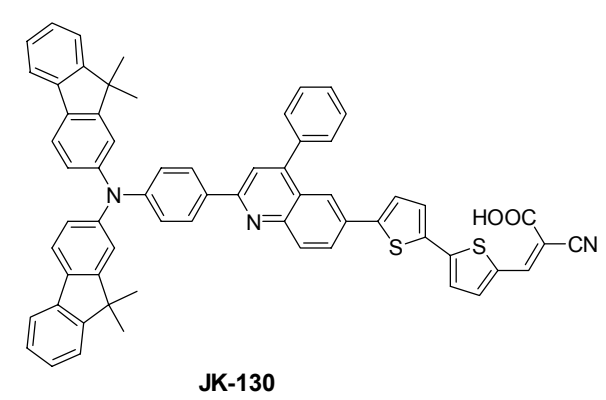

JK-130

Figure 1. Structure of the dyes of JK-128, JK-129 and JK-130. 

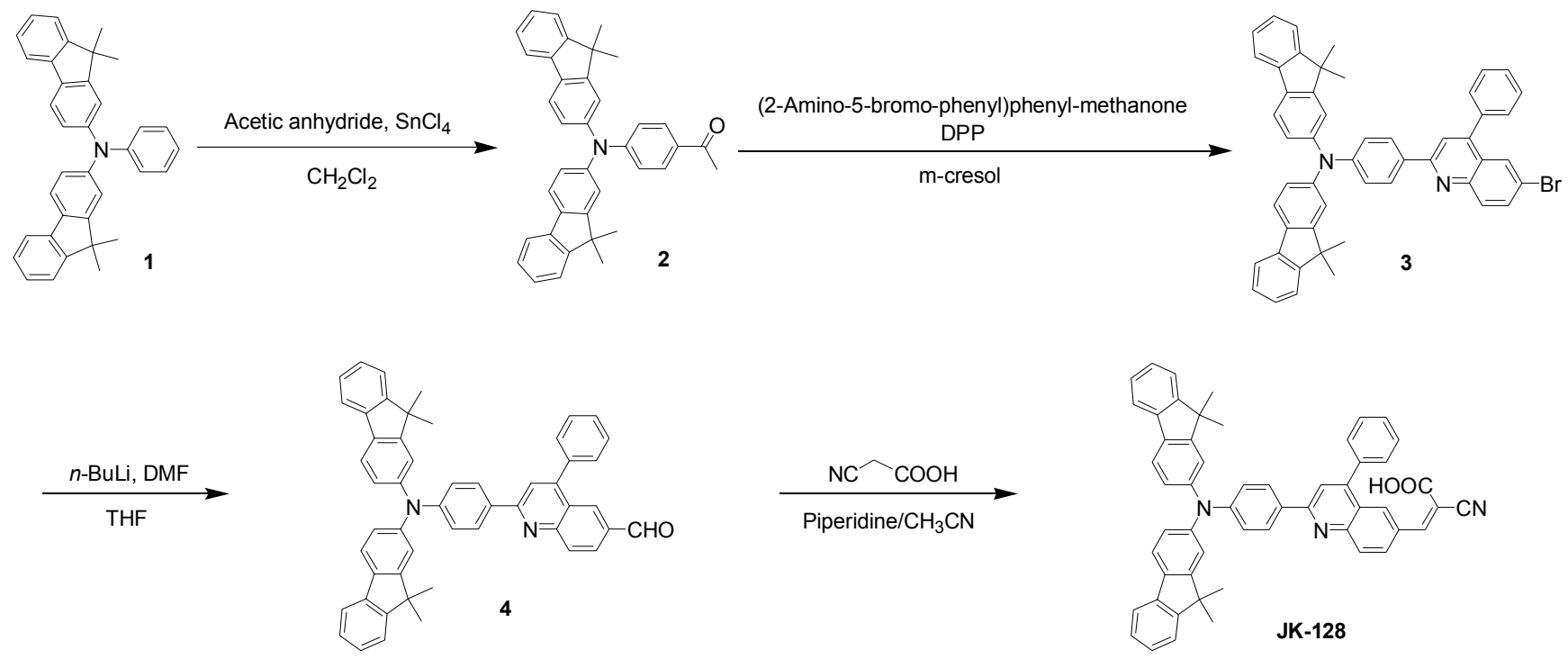

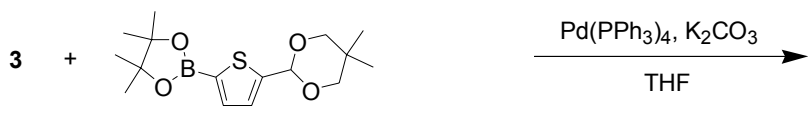
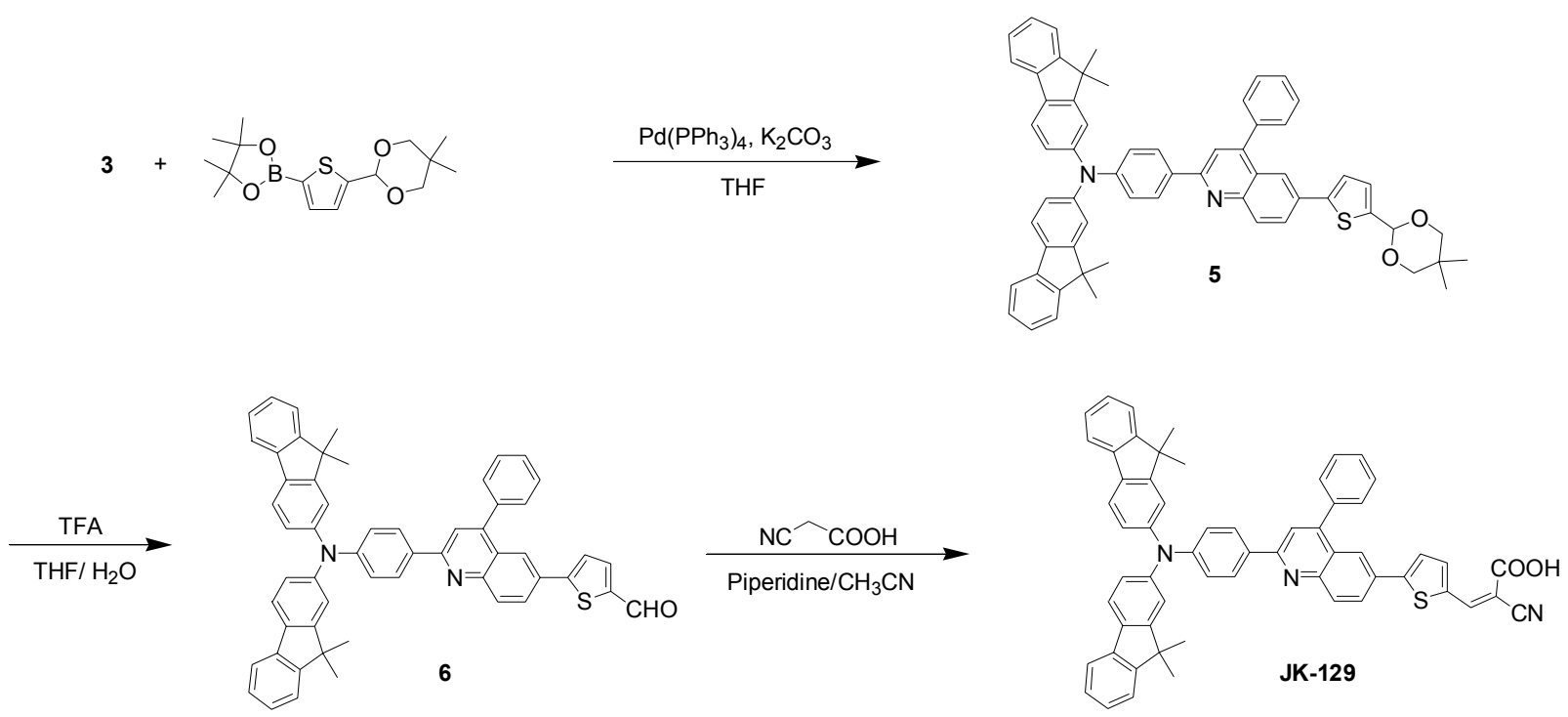

$3+$ +O $_{0}$
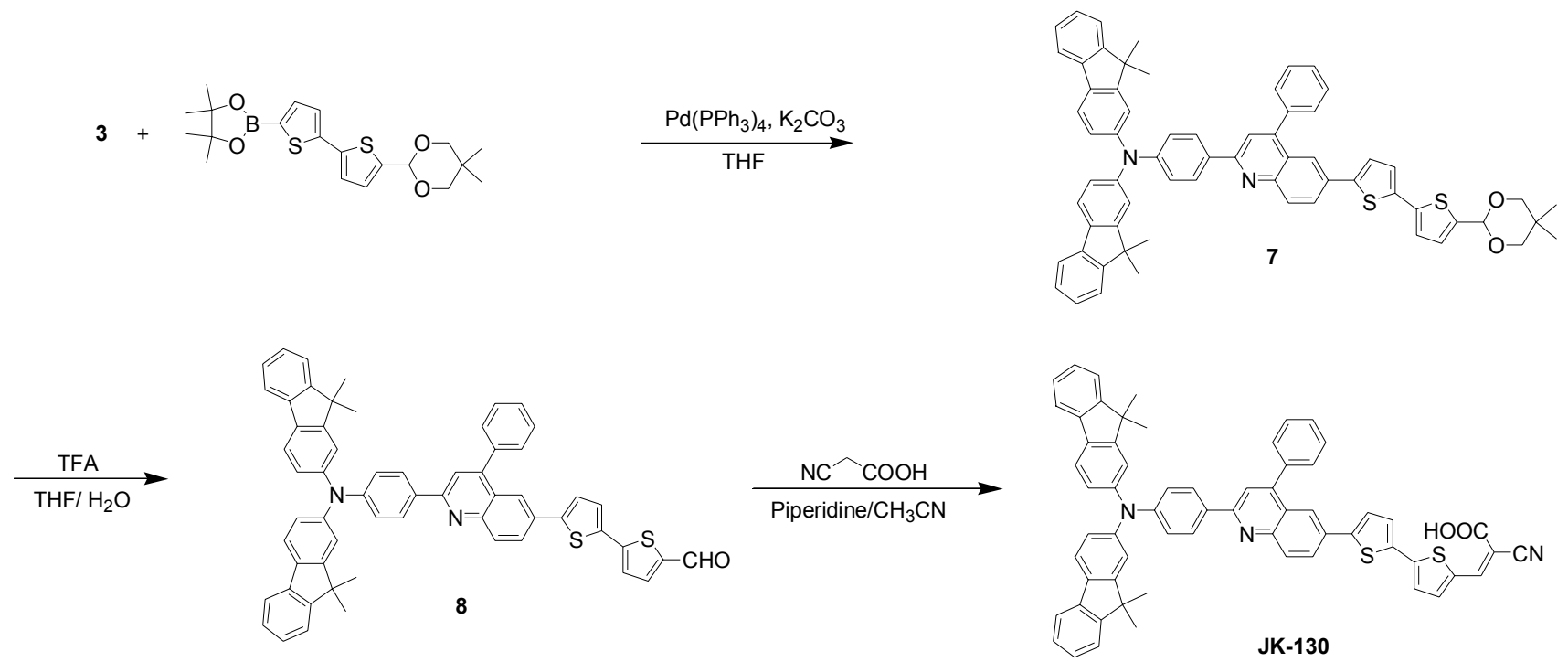

Scheme 1. Schematic diagram for the synthesis of JK-128, JK-129 and JK-130 


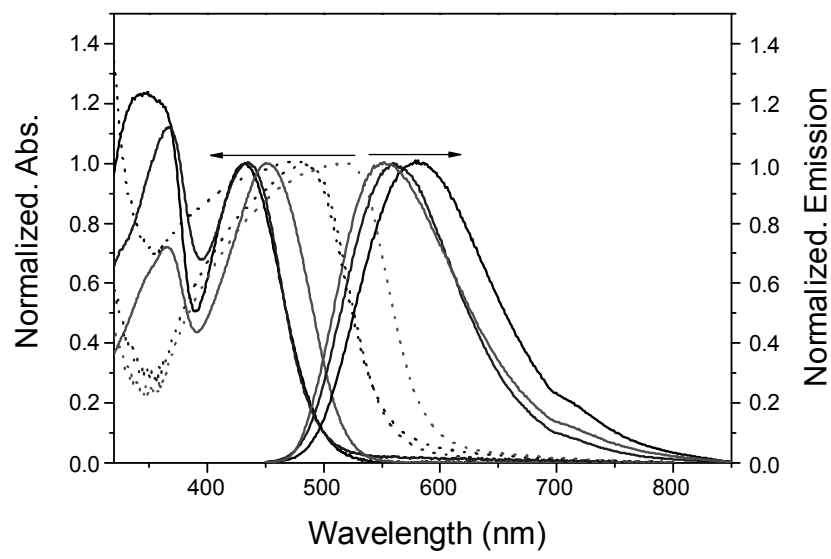

Figure 2. Absorption and emission spectra of JK-128 (black solid line), JK-129 (blue solid line) and JK-130 (red solid line) in THF and absorption spectra of JK-128 (black dash line), JK-129 (blue dash line) and JK-130 (red dash line) absorbed on $\mathrm{TiO}_{2}$ film.

one (2) was readily synthesized via a Friedel-Craft acylation reaction. The Friedlander condensation reaction ${ }^{15}$ of $\mathbf{2}$ with (2-amino-5-bromo-phenyl)phenyl-methanone in the presence of diphenyl phosphate yielded $\mathbf{3}$. Compound $\mathbf{4}$ was prepared from 3 by a lithiation with 1.2 equiv of $n$-butyllithium and subsequent quenching with DMF. The aldehyde 4, on reaction with cyanoacetic acid in the presence of piperidine in $\mathrm{CH}_{3} \mathrm{CN}$ gave the JK-128 dye. The JK-129 and JK-130 dyes were synthesized by Suzuki coupling reaction ${ }^{16}$ of 6-bromo-phenylquinoline derivatives with 1.2 equiv of 2-(5-thiophen-2-yl)-1,3,2dioxaborolane or 2-(2,2'-bithiophen-5-yl)-1,3,2-dioxaborolane, followed by dedioxanylation of $\mathbf{5}$ and $\mathbf{7}$ with trifluoroacetic acid.

Fig. 2 shows the absorption and emission spectra of the JK-128, JK-129, and JK-130 sensitizers measured in THF and the data are listed in Table 1. The absorption spectrum of JK-128 displays two absorption maxima at $431 \mathrm{~nm}\left(\varepsilon=22,500 \mathrm{dm}^{3}\right.$ $\left.\mathrm{mol}^{-1} \mathrm{~cm}^{-1}\right)$ and $352 \mathrm{~nm}\left(\varepsilon=27,500 \mathrm{dm}^{3} \mathrm{~mol}^{-1} \mathrm{~cm}^{-1}\right)$, which are due to the $\pi-\pi^{*}$ transitions of the conjugated system. Under the same conditions the JK-129 sensitizer that contains the thiophene unit exhibits absorption bands at $435 \mathrm{~nm}(\varepsilon=28,100$ $\left.\mathrm{dm}^{3} \mathrm{~mol}^{-1} \mathrm{~cm}^{-1}\right)$ and $367 \mathrm{~nm}\left(\varepsilon=31,000 \mathrm{dm}^{3} \mathrm{~mol}^{-1} \mathrm{~cm}^{-1}\right)$ that are red-shifted about 4 and $15 \mathrm{~nm}$ when compared with those of JK-128. On the other hand, the introduction of bithiophene unit, giving JK-130, causes a further red shift to $453 \mathrm{~nm}(\varepsilon=$ $51,000 \mathrm{dm}^{3} \mathrm{~mol}^{-1} \mathrm{~cm}^{-1}$ ) compared to the JK-128 and JK-129 sensitizers. ${ }^{6}$ Such a high molar extinction coefficient and red

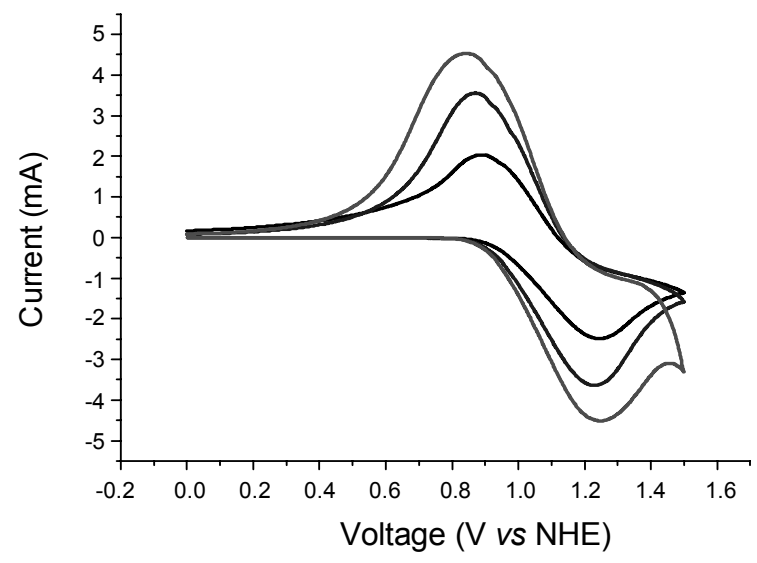

Figure 3. Cyclic voltammograms of JK-128 (black solid line), JK-129 (blue solid line), and JK-130 (red solid line).

shift result from the extension of the $\pi$-conjugation in the sensitizer due to the introduction of bithiophene unit in the bridged framework. When the JK-128, JK-129, and JK-130 sensitizers were adsorbed on $\mathrm{TiO}_{2}$ electrode, a large red shift of $44 \sim 72 \mathrm{~nm}$ was found due to the $J$-aggregation. ${ }^{17}$ The absorption spectra of the three dyes on $\mathrm{TiO}_{2}$ are much broadened due to an interaction between the dyes and $\mathrm{TiO}_{2}{ }^{6}$ Such broadening and red shift of the absorption spectra are desirable for harvesting the solar spectrum and lead to large photocurrent. When the JK-128, JK-129, and JK-130 sensitizers are excited within their $\pi-\pi^{*}$ bands in an air-equilibrated solution and at $298 \mathrm{~K}$, they exhibit strong luminescence maxima at 556, 564, and $594 \mathrm{~nm}$, respectively.

Electrochemical properties of the dyes JK-128 $~$ JK-130 were scrutinized by cyclovoltammetry in acetonitrile containing $0.1 \mathrm{M}$ tetrabutyl ammonium hexafluoro-phosphate. $\mathrm{TiO}_{2}$ films stained with the sensitizers were used as working electrodes. The three organic dyes absorbed on $\mathrm{TiO}_{2}$ film show quasi-reversible couples (Fig. 3). The oxidation potential of JK-128 was measured to be $1.16 \mathrm{~V}$ versus NHE with a separation of $0.36 \mathrm{~V}$ between anodic-to-cathodic peak. Under similar conditions the JK-129 and JK-130 dyes exhibits the redox couples at 1.14 and $1.13 \mathrm{~V}$ versus NHE, respectively. The redox potentials of the three dyes were calculated from the oxidation potential and the $E_{0-0}$ determined from the intersection of absorption and emission spectra (Table 1). The excited state oxidation potentials $\left(E_{\mathrm{OX}}^{*}\right)$ of the sensitizers (JK-128:-1.33 V; JK-129:-1.38 V; JK-130:

Table 1. Optical, redox and DSSC performance parameters of dyes

\begin{tabular}{ccccccccc}
\hline \multirow{2}{*}{ Dye } & $\lambda_{\text {abs }}{ }^{a} / \mathrm{nm}\left(\varepsilon / \mathrm{M}^{-1} \mathrm{~cm}^{-1}\right)$ & $E_{\text {redox }}{ }^{b} / \mathrm{V}$ & $E_{0-0}{ }^{c} / \mathrm{V}$ & $E_{\mathrm{LUMO}}{ }^{d} / \mathrm{V}$ & $J_{\text {sc }}\left(\mathrm{mAcm}^{-2}\right)$ & $V_{\text {oc }}(\mathrm{V})$ & $\mathrm{FF}$ & $\eta^{\mathrm{e}}(\%)$ \\
\hline JK-128 & $352(27500), 431(22500)$ & 1.16 & 2.49 & -1.33 & 7.568 & 0.7671 & 78.34 & 4.55 \\
JK-129 & $367(31000), 435(28100)$ & 1.14 & 2.52 & -1.38 & 8.289 & 0.7059 & 77.50 & 4.53 \\
JK-130 & $320(36800), 453(51000)$ & 1.13 & 2.48 & -1.35 & 11.519 & 0.6998 & 75.29 & 6.07 \\
\hline
\end{tabular}

${ }^{a}$ Absorption spectra measured in THF solution. ${ }^{b}$ Redox potential of dyes on $\mathrm{TiO}_{2}$ were measured in $\mathrm{CH}_{3} \mathrm{CN}$ with $0.1 \mathrm{M}\left(n \text { - } \mathrm{C}_{4} \mathrm{H}_{9}\right)_{4} \mathrm{NPF}_{6}$ with a scan rate of $50 \mathrm{mVs}^{-1}$ (vs. NHE). ${ }^{c} E_{0-0}$ was determined from intersection of absorption and emission spectra in THF. ${ }^{d} E_{\mathrm{LUMO}}$ was calculated by $E_{\mathrm{OX}}-E_{0-0}$. ${ }^{e}$ Performances of DSSCs were measured with $0.18 \mathrm{~cm}^{2}$ working area. Electrolyte $0.6 \mathrm{M}$ DMOImI, $0.05 \mathrm{M} \mathrm{I}_{2}, 0.1 \mathrm{M}$ LiI, and $0.5 \mathrm{M}$ tert-butylpyridine in acetonitrile. 
(a)

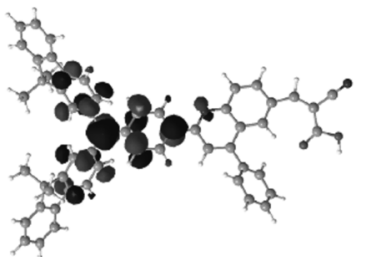

HOMO

(b)

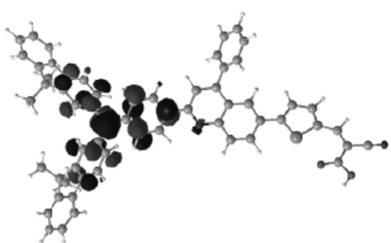

HOMO

(c)

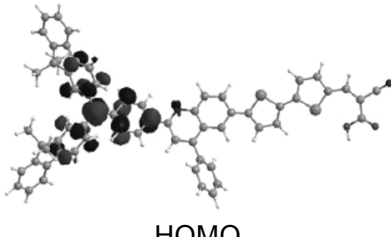

HOMO

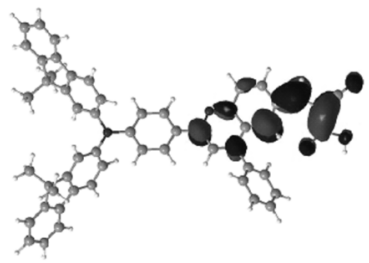

LUMO

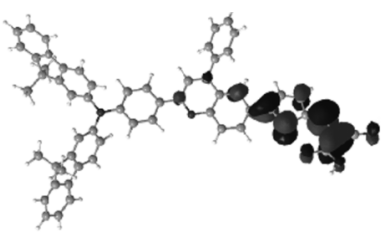

LUMO

Figure 4. Isodensity surface plots of the HOMO and LUMO of (a) JK-128, (b) JK-129 and (c) JK-130.

$-1.35 \mathrm{~V} v s$. NHE) are much negative than the conduction band level of $\mathrm{TiO}_{2}$ at approximately $-0.5 \mathrm{~V}$ versus $\mathrm{NHE}$, indicating that the electron injection should be thermodynamically favourable. $^{18}$

To gain insight into the characteristic features of the electronic structure, molecular orbital calculations of three sensitizers were performed with the TD-DFT on B3LYP $/ 3-21 \mathrm{G}^{*}$. The calculations indicate that the HOMO of three dyes is localized over the fluorenylamino unit over phenyl and the LUMO of JK-128 is localized over the cyanoacrylic unit through the extension of the quinoline unit (Fig. 4). On the other hand, the LUMO of JK-129 and JK-130 is localized through the cyanoacrylic and thiophene moieties. Examination of the HOMO and LUMO of the three dyes indicates that the excitation of the dyes moved the electron distribution from the amino unit to the cyanoacrylic acid unit. Therefore the change in electron distribution induced by photoexcitation results in an efficient charge separation.

Fig. 5 shows action spectra of monochromatic incidentto-current conversion efficiencies (IPCEs) for DSSCs based on JK-128 JK-130. The onset of IPCE spectra for DSSCs based on JK-128 and JK-129 is $650 \mathrm{~nm}$. On the other hand, the onset of JK-130 tails off toward $690 \mathrm{~nm}$, contributing to the broad spectral light harvesting. Furthermore, the enhanced light harvesting of JK-130 in the $550 \sim 650 \mathrm{~nm}$ due to the introduction of bithiophene can be clearly seem from Figure 5 . The IPCE of JK-130 sensitizer exceeds $80 \%$ in the spectral region from 400 to $550 \mathrm{~nm}$, reaching its maximum of $85 \%$ at $435 \mathrm{~nm}$. Integrating the IPCE curve of JK-130 over the solar spectrum results in a short circuit current of $11.31 \mathrm{~mA} \mathrm{~cm}^{-2}$ in agreement with the measured device photocurrent. In addition, we find

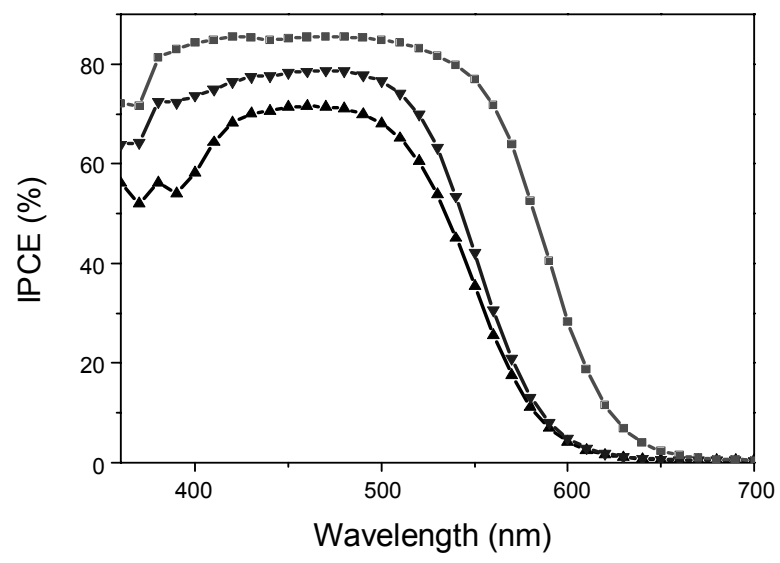

Figure 5. Spectra of incident photon-to-current conversion efficiencies (IPCEs) for DSSC based on JK-128 (black line), JK-129 (blue line), and JK-130 (red line).

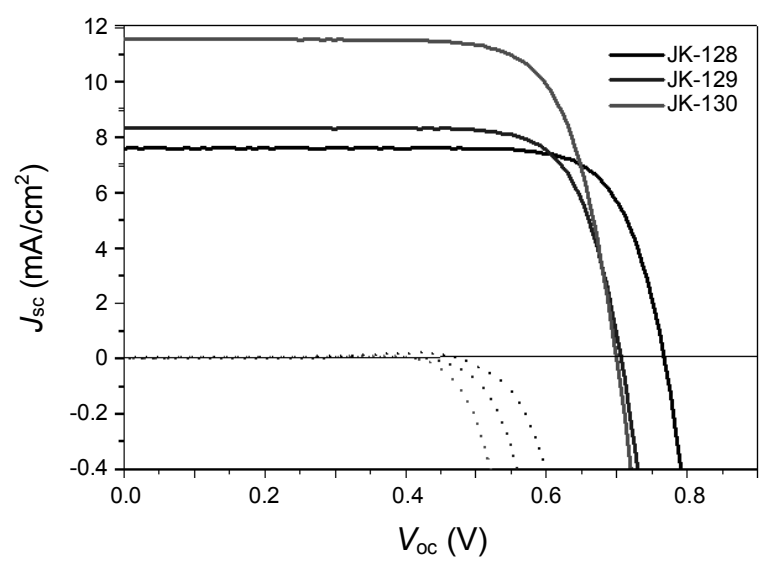

Figure 6. J-V curve of JK-128 (black solid line), JK-129 (blue solid line) and JK-130 (red solid line). Dark current-bias potential relationship is shown as dotted curves.

that the device based on JK-130 exhibits a significant increase in the short circuit current density $\left(J_{\mathrm{sc}}\right)$. This observation most probably stems from the high molar extinction coefficient and the red shift in the absorption spectrum of $\mathbf{J K - 1 3 0}$ relative to JK-128 and JK-129. The J-V curve for the cells based on the JK-128 $\sim$ JK-130 is presented in Figure 6. Under standard global AM 1.5 solar condition, the JK-128 and JK-129 sensitized cell gave a short circuit photocurrent density $\left(J_{\mathrm{sc}}\right)$ of 7.57 and $8.29 \mathrm{~mA} \mathrm{~cm}^{-2}$, an open circuit voltage $\left(V_{\mathrm{oc}}\right)$ of 0.77 and $0.71 \mathrm{~V}$ and a fill factor of 0.78 and 0.77 , corresponding to an overall conversion efficiency $\eta$ of 4.55 and $4.53 \%$, respectively. Under the same condition, the JK-130 sensitized cell gave a $J_{\text {sc }}$ of $11.52 \mathrm{~mA} \mathrm{~cm}^{-2}, V_{\text {oc }}$ of $0.70 \mathrm{~V}$ and a fill factor of 0.75 corresponding to $\eta$ of $6.07 \%$. Of particular importance is the $3.23 \sim 3.95 \mathrm{~mA} \mathrm{~cm}^{-2}$ increase in $J_{\mathrm{sc}}$ of the $\mathbf{J K} \mathbf{- 1 3 0}$ cell. In order to explain the high photocurrent of JK-130, we have measured the amount of dyes absorbed on $\mathrm{TiO}_{2}$ film. The absorbed amount of $1.98 \times 10^{-6} \mathrm{mmol} \mathrm{cm}^{-2}$ for $\mathbf{J K}-\mathbf{1 2 8}, 2.64 \times 10^{-6} \mathrm{mmol} \mathrm{cm}^{-2}$ for JK-129, and $2.54 \times 10^{-6} \mathrm{mmol} \mathrm{cm}^{-2}$ for $\mathbf{J K - 1 3 0}$ are observed. Therefore, the large photocurrent in $\mathbf{J K - 1 3 0}$ is attributable to a broad and intense absorption spectrum rather than their absorbed amounts. 
(a)

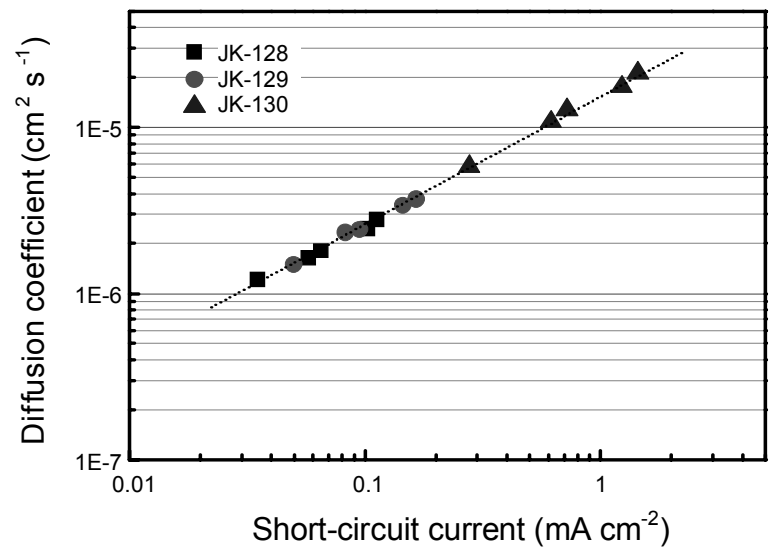

(b)

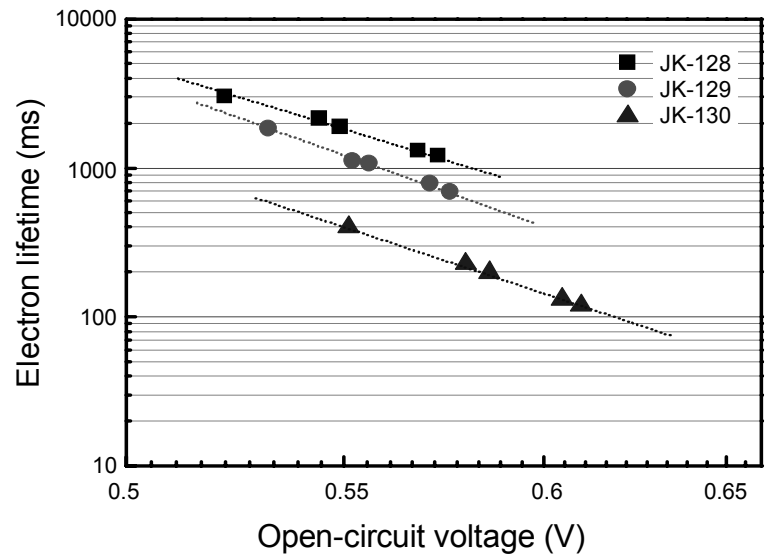

Figure 7. Electron diffusion coefficients (a) and lifetimes (b) of the DSSCs employing JK-128, JK-129, and JK-130, respectively.

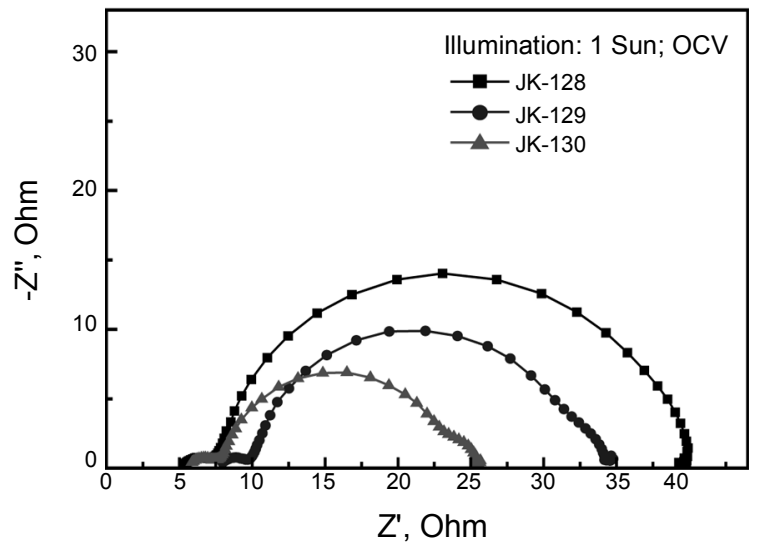

Figure 8. Electrochemical impedance spectra measured under the illumination $\left(100 \mathrm{~mW} \mathrm{~cm}^{-2}\right)$ for the devices employing different dyes (ロ JK-128, • JK-129, ^ JK-130).

To understand the electron injection property and the change in $V_{\text {oc }}$ of $\mathbf{J K - 1 2 8 , ~ J K - 1 2 9 , ~ a n d ~} \mathbf{J K - 1 3 0 , ~ w e ~ m e a s u r e d ~ e l e c t r o n ~}$ diffusion coefficients and lifetimes in the photoelectrode. Fig. 7 shows the electron diffusion coefficients and lifetimes of the DSSCs employing different dyes (i.e. JK-128, JK-129, and JK-130) displayed as a function of the $J_{s c}$ and $V_{o c}$, respectively. No significant differences among the $D_{e}$ values were seen at the identical short-circuit current conditions, showing the similar trend to those of coumarin dyes. ${ }^{6 \mathrm{~b}}$ On the other hand, the $\tau_{e}$ values show a significant gap among the dyes, resulting in the increasing order of JK-128 $>\mathbf{J K - 1 2 9}>\mathbf{J K}-\mathbf{1 3 0}$. The increase in the number of thiophene unit enhances the light absorption of long wavelength, and therefore the $J_{s c}$ significantly increases but the $V_{o c}$ decreases simultaneously as shown in Table 1 . The results of the electron lifetime are also well consistent with those of the $V_{o c}$.

Fig. 8 shows the ac impedance spectra of the DSSCs measured under the illumination conditions. Under the illumination (100 $\mathrm{mW} \mathrm{cm}^{-2}$, open-circuit voltage (OCV) condition), the radius of the intermediate-frequency semicircle in the Nyquist plot decreased in the order of JK-128 $(32.1 \Omega)>\mathbf{J K}-129(17.7$ $\Omega)>\mathbf{J K}-130(10.5 \Omega)$, indicating the improved electron generation and transport. This result also well corresponds to that of the overall efficiency.

In summary, We have designed and synthesized three organic sensitizers containing a quinoline unit. We obtained a maximum solar energy to electricity conversion efficiency $(\eta)$ of $6.07 \%$ under AM 1.5 irradiation with a DSSC based on JK-130. Our results suggest that the development of efficient sensitizers comparable to ruthenium dyes can be possible through the structural modifications of bridging units and these works are now in progress.

\section{Experimental Section}

General methods. All reactions were carried out under argon atmosphere. Solvents were distilled from appropriate reagents. All reagents were purchased from Sigma-Aldrich and TCI. 9,9-Dimethyl- $N$-(9,9-dimethyl-9H-fluoren-7-yl)- $N$-phenyl-9 $H$-fluoren-2-amine ${ }^{10}$ and (2-amino-5-bromophenyl)phenyl-methanone ${ }^{19}$ were synthesized using a modified procedure of previous references. ${ }^{1} \mathrm{H}$ and ${ }^{13} \mathrm{C}$ NMR spectra were recorded on a Varian Mercury 300 spectrometer. Elemental analyses were recorded on a JEOL JMS-SX102A instruments CHNS-OEA 1108 analyzer. The absorption and photoluminescence spectra were recorded on a Perkin-Elmer Lambda 2S UV-visible spectrometer and a Perkin LS fluorescence spectrometer, respectively.

Cyclovoltamogram: Cyclic voltammetry was carried out with a BAS 100B (Bioanalytical Systems, Inc.). A three-electrode system was used and consisted of a gold disk, working electrode, a platinum wire electrode. Redox potential of dyes on $\mathrm{TiO}_{2}$ were measured in $\mathrm{CH}_{3} \mathrm{CN}$ with $0.1 \mathrm{M}\left(n-\mathrm{C}_{4} \mathrm{H}_{9}\right)_{4} \mathrm{~N}-\mathrm{PF}_{6}$ with a scan rate of $50 \mathrm{mV} \mathrm{s}^{-1}$ (vs. $\left.\mathrm{Fc} / \mathrm{Fc}^{+}\right)$.

Dye-sensitized solar cell Fabrication: FTO glass plates (Pilkington TEC Glass-TEC 8, Solar $2.3 \mathrm{~mm}$ thickness) were cleaned in a detergent solution using an ultrasonic bath for 30 min, rinsed with water and ethanol. The FTO glass plates were immersed in $40 \mathrm{mM} \mathrm{TiCl}_{4}$ (aqueous) at $70{ }^{\circ} \mathrm{C}$ for $30 \mathrm{~min}$ and washed with water and ethanol. A transparent nanocrystalline layer on the FTO glass plate was prepared by doctor blade printing $\mathrm{TiO}_{2}$ paste (Solaronix, Ti-Nanoxide T/SP) and then dried for $2 \mathrm{~h}$ at $25{ }^{\circ} \mathrm{C}$. The $\mathrm{TiO}_{2}$ electrodes were gradually heated under an air flow at $325^{\circ} \mathrm{C}$ for $5 \mathrm{~min}$, at $375^{\circ} \mathrm{C}$ for 5 min, at $450{ }^{\circ} \mathrm{C}$ for $15 \mathrm{~min}$, and at $500{ }^{\circ} \mathrm{C}$ for $15 \mathrm{~min}$. The thickness of the transparent layer was measured by using an Alpha- 
step 250 surface profilometer (Tencor Instruments, San Jose, CA), a paste for the scattering layer containing $400 \mathrm{~nm}$ sized anatase particles (CCIC, PST-400C) was deposited by doctor blade printing and then dried for $2 \mathrm{~h}$ at $25{ }^{\circ} \mathrm{C}$. The $\mathrm{TiO}_{2}$ electrodes were gradually heated under an air flow at $325^{\circ} \mathrm{C}$ for $5 \mathrm{~min}$, at $375^{\circ} \mathrm{C}$ for $5 \mathrm{~min}$, at $450^{\circ} \mathrm{C}$ for $15 \mathrm{~min}$, and at $500^{\circ} \mathrm{C}$ for $15 \mathrm{~min}$. The resulting layer was composed of $20 \mu \mathrm{m}$ thickness of transparent layer and $4 \mu \mathrm{m}$ thickness of scattering layer. The $\mathrm{TiO}_{2}$ electrodes were treated again by $\mathrm{TiCl}_{4}$ at $70{ }^{\circ} \mathrm{C}$ for $30 \mathrm{~min}$ and sintered at $500{ }^{\circ} \mathrm{C}$ for $30 \mathrm{~min}$. The $\mathrm{TiO}_{2}$ electrodes were immersed into the JK-128, JK-129 and JK-130 (0.3 mM in THF) containing $10 \mathrm{mM} 3 \mathrm{a}, 7 \mathrm{a}$-dihydroxy-5b-cholic acid (Cheno)) and kept at room temperature for $24 \mathrm{~h}$. The FTO plate (Pilkington TEC Glass-TEC 8, Solar $2.3 \mathrm{~mm}$ thickness) for counter electrodes cleaned with ultrasonic bath in $\mathrm{H}_{2} \mathrm{O}$, acetone and $0.1 \mathrm{M} \mathrm{HCl} a q$., subsequently. Counter electrodes were prepared by coating with a drop of $\mathrm{H}_{2} \mathrm{PtCl}_{6}$ solution $(2 \mathrm{mg}$ of Pt in $1 \mathrm{~mL}$ of ethanol) on a FTO plate and heating at $400{ }^{\circ} \mathrm{C}$ for $15 \mathrm{~min}$. The dye adsorbed $\mathrm{TiO}_{2}$ electrode and Pt-counter electrode were assembled into a sealed sandwich-type cell by heating at $80^{\circ} \mathrm{C}$ with a hot-melt ionomer film (Surlyn SX 1170-25, Solaronix) as a spacer between the electrodes. A drop of electrolyte solution (electrolyte of $0.6 \mathrm{M}$ 1-hexyl-2,3-dimethylimidazolium iodide, $0.05 \mathrm{M}$ iodine, $0.1 \mathrm{M} \mathrm{LiI}$, and $0.5 \mathrm{M}$ tertbutylpyridine in acetonitrile) was placed on the drilled hole in the counter electrode of the assembled cell and was driven into the cell via vacuum backfilling. Finally, the hole was sealed using additional Surlyn and a cover glass (0.1 mm thickness).

Electron transport measurements: The electron diffusion coefficient $\left(D_{e}\right)$ and lifetimes $\left(\tau_{e}\right)$ in $\mathrm{TiO}_{2}$ photoelectrode were measured by the stepped light-induced transient measurements of photocurrent and voltage (SLIM-PCV). ${ }^{20-24}$ The transients were induced by a stepwise change in the laser intensity. A diode laser $(\lambda=635 \mathrm{~nm})$ as a light source was modulated using a function generator. The initial laser intensity was a constant $90 \mathrm{~mW} \mathrm{~cm}^{-2}$ and was attenuated up to approximately $10 \mathrm{~mW}$ $\mathrm{cm}^{-2}$ using a ND filter which was positioned at the front side of the fabricated samples $\left(\mathrm{TiO}_{2}\right.$ film thickness $=c a .10 \mu \mathrm{m}$; active area $=0.04 \mathrm{~cm}^{2}$ ). The photocurrent and photovoltage transients were monitored using a digital oscilloscope through an amplifier. The $D_{e}$ value was obtained by a time constant $\left(\tau_{c}\right)$ determined by fitting a decay of the photocurrent transient with $\exp \left(-\mathrm{t} / \tau_{c}\right)$ and the $\mathrm{TiO}_{2}$ film thickness $(\omega)$ using the equation, $D_{e}=\omega^{2} /$ $\left(2.77 \tau_{c}\right) .{ }^{17}$ The $\tau_{e}$ value was also determined by fitting a decay of photovoltage transient with $\exp \left(-\mathrm{t} / \tau_{e}\right) .{ }^{17}$ All experiments were conducted at room temperature.

1-(4-(Bis(9,9-dimethyl-9H-fluoren-2-yl)amino)phenyl)ethanone (2): To a stirred solution of the compound 1 ( $0.615 \mathrm{~g}$, $1.3 \mathrm{mmol}$ ) in $\mathrm{CH}_{2} \mathrm{Cl}_{2}$ was added a solution of acetic anhydride in dry $\mathrm{CH}_{2} \mathrm{Cl}_{2}$ (1.1 equiv) and a solution of $\mathrm{SnCl}_{4}$ (1.1 equiv) in dry $\mathrm{CH}_{3} \mathrm{CN}$. The mixture was refluxed for $24 \mathrm{~h}$ and then poured over ice containing glacial acetic acid. The organic layer was separated and dried in $\mathrm{MgSO}_{4}$. The product 2 was obtained by silica gel column chromatography (eluent $\mathrm{EA}: \mathrm{Hx}=1: 3) .{ }^{1} \mathrm{H}$ NMR $\left(\mathrm{CDCl}_{3}\right) \delta 7.84(\mathrm{~d}, J=9.0 \mathrm{~Hz}, 2 \mathrm{H}), 7.66(\mathrm{t}, J=7.2 \mathrm{~Hz}$, $4 \mathrm{H}), 7.41(\mathrm{~d}, J=6.3 \mathrm{~Hz}, 2 \mathrm{H}), 7.31(\mathrm{t}, J=5.7 \mathrm{~Hz}, 4 \mathrm{H}), 7.25(\mathrm{~d}$, $J=2.1 \mathrm{~Hz}, 2 \mathrm{H}), 7.16-7.11(\mathrm{~m}, 4 \mathrm{H}), 2.56(\mathrm{~s}, 3 \mathrm{H}), 1.42$ (s, 12H). ${ }^{13} \mathrm{C} \mathrm{NMR}\left(\mathrm{CDCl}_{3}\right) \delta 196.7,155.4153 .7,152.5,146.1,141.9$,
$138.7,135.8,130.2,130.0,127.1,125.2,124.3,122.8,121.0$, 120.3, 120.0, 47.1, 27.3, 27.0. MS: $m / z 519\left[\mathrm{M}^{+}\right]$. Anal. Calc. for $\mathrm{C}_{38} \mathrm{H}_{33} \mathrm{NO}$ : C, 87.83; H, 6.40. Found: C, 87.61; H, 6.19.

$\mathrm{N}$-(4-(6-Bromo-4-phenylquinolin-2-yl)phenyl)-9,9-dimethyl- $\mathrm{N}-(9,9-d i m e t h y l-9 H$-fluoren-7-yl)-9H-fluoren-2-amine (3): A mixture of compound $2(0.412 \mathrm{~g}, 0.79 \mathrm{mmol})$, diphenyl phosphate (DPP, $0.422 \mathrm{~g}, 1.68 \mathrm{mmol}$ ) and (2-amino-5-bromophenyl)phenyl-methanone $(0.24 \mathrm{~g}, 0.87 \mathrm{mmol})$ in m-cresol (2 $\mathrm{mL}$ ) was stirred at room temperature for $20 \mathrm{~min}$ and then refluxed at $140{ }^{\circ} \mathrm{C}$ for $12 \mathrm{~h}$. The solution was extracted with $\mathrm{CH}_{2} \mathrm{Cl}_{2}$, and dried with $\mathrm{MgSO}_{4}$. The yellow product 3 was obtained by silica gel column chromatography (eluent EA : $\mathrm{Hx}=1: 10)$. ${ }^{1} \mathrm{H} \mathrm{NMR}\left(\mathrm{CDCl}_{3}\right) \delta 8.08(\mathrm{t}, J=8.7 \mathrm{~Hz}, 3 \mathrm{H}), 8.02(\mathrm{~d}, J=1.5 \mathrm{~Hz}$, $1 \mathrm{H}), 7.81(\mathrm{~s}, 1 \mathrm{H}), 7.78(\mathrm{~d}, J=8.7 \mathrm{~Hz}, 1 \mathrm{H}), 7.72(\mathrm{~d}, J=1.8 \mathrm{~Hz}, 1 \mathrm{H})$, 7.68-7.53 (m, 10H), 7.42 (d, J=14.7 Hz, 2H), 7.37-7.28 (m, 6H), $7.16(\mathrm{~d}, J=8.1 \mathrm{~Hz}, 2 \mathrm{H}), 1.43(\mathrm{~s}, 12 \mathrm{H}) .{ }^{13} \mathrm{C} \mathrm{NMR}\left(\mathrm{CDCl}_{3}\right) \delta$ $156.9,155.3,153.7,149.6,148.3,147.6,147.0,139.0,137.9$, $134.8,133.1,132.7,131.8,129.6,129.4,128.9,128.8,128.6$, 126.9, 126.8, 123.9, 123.5, 122.7, 120.8, 120.1, 119.8, 119.6, 119.3, 47.0, 27.2. MS: $m / z 758\left[\mathrm{M}^{+}\right]$. Anal. Calc. for $\mathrm{C}_{51} \mathrm{H}_{39} \mathrm{BrN}_{2}$ : C, 80.62; H, 5.17. Found: C, 80.41; H, 4.95.

3-(4-(Bis(9,9-dimethyl-9H-fluoren-2-yl)amino)phenyl)-4phenylquinoline-6-carbaldehyde (4): Under a nitrogen atmosphere, $n$-BuLi (0.143 mL, $2.5 \mathrm{M}$ solution in hexane) was dropwise added into compound $3(0.247 \mathrm{~g}, 0.33 \mathrm{mmol})$ solution in dry tetrahydrofuran (THF) and the mixture was stirred at $-10^{\circ} \mathrm{C}$ for $1 \mathrm{~h}$. After dimethylformamide $(0.027 \mathrm{~mL}, 0.34 \mathrm{mmol})$ was added to the reaction mixture, the solution was then left under stirring overnight at room temperature. After solvent was evaporated, the organic layer was separated and dried in $\mathrm{MgSO}_{4}$. The product 4 was obtained by silica gel column chromatography (eluent EA : $\mathrm{Hx}=1: 5) .{ }^{1} \mathrm{H} \mathrm{NMR}\left(\mathrm{CDCl}_{3}\right) \delta 10.10(\mathrm{~s}$, $1 \mathrm{H}), 8.38(\mathrm{~s}, 1 \mathrm{H}), 8.30(\mathrm{~d}, J=8.7 \mathrm{~Hz}, 1 \mathrm{H}), 8.20(\mathrm{t}, J=8.4 \mathrm{~Hz}$, $3 \mathrm{H}), 7.90(\mathrm{~s}, 1 \mathrm{H}), 7.69-7.25(\mathrm{~m}, 19 \mathrm{H}), 7.17(\mathrm{~d}, J=8.1 \mathrm{~Hz}$, $2 \mathrm{H}), 1.44(\mathrm{~s}, 12 \mathrm{H}) .{ }^{13} \mathrm{C} \mathrm{NMR}\left(\mathrm{CDCl}_{3}\right) \delta 191.8,159.0,155.3$, $153.7,151.9,150.6,150.1,146.8,138.9,137.7,136.2,135.6$, $135.1,133.8,133.2,132.2,132.1,131.2,129.6,129.1,128.9$, 127.2, 126.8, 125.2, 124.0, 122.9, 122.6, 121.5, 120.8, 119.8, 119.7, 119.4, 48.2, 27.2. MS: $m / z 708\left[\mathrm{M}^{+}\right]$. Anal. Calc. for $\mathrm{C}_{52} \mathrm{H}_{40} \mathrm{~N}_{2} \mathrm{O}$ : C, 88.10; H, 5.69. Found: C, 87.89; H, 5.48.

(Z)-3-(3-(4-(Bis(9,9-dimethyl-9H-fluoren-2-yl)amino)phenyl)-4-phenylquinolin-6-yl)-2-cyanoacrylic acid (JK-128): A mixture of compound $4(0.09 \mathrm{~g}, 0.13 \mathrm{mmol})$ and cyanoacetic acid $(0.02 \mathrm{~g}, 0.25 \mathrm{mmol})$ were added $\mathrm{CH}_{3} \mathrm{CN}(30 \mathrm{~mL})$ and piperidine $(0.02 \mathrm{~g}, 0.23 \mathrm{mmol})$. The solution was refluxed for $6 \mathrm{~h}$. After cooling the solution, the organic layer was removed in vacuo. The crude product was extracted with $\mathrm{CH}_{2} \mathrm{Cl}_{2}$ and water. The pure product JK-128 was obtained by silica gel column chromatography (eluent $\mathrm{MC}: \mathrm{MeOH}=9: 1$ ). ${ }^{1} \mathrm{H} \mathrm{NMR}$ $\left(\mathrm{DMSO}-d_{6}\right) \delta 8.30(\mathrm{~d}, J=15.3 \mathrm{~Hz}), 8.23(\mathrm{~s}, 1 \mathrm{H}), 8.17(\mathrm{~s}, 1 \mathrm{H})$, $8.06(\mathrm{~s}, 1 \mathrm{H}), 7.97(\mathrm{~s}, 1 \mathrm{H}), 7.79(\mathrm{t}, J=10.8 \mathrm{~Hz}, 4 \mathrm{H}), 7.68-7.28$ $(\mathrm{m}, 14 \mathrm{H}), 7.19(\mathrm{~d}, J=6.3 \mathrm{~Hz}, 2 \mathrm{H}), 7.11(\mathrm{~d}, J=7.8 \mathrm{~Hz}, 2 \mathrm{H}), 1.40$ $(\mathrm{s}, 12 \mathrm{H}) .{ }^{13} \mathrm{C}$ NMR (DMSO- $\left.d_{6}\right) \delta 163.3,162.7,156.4,154.9$, 153.3, 149.2, 149.0, 148.9, 146.8, 146.2, 139.5, 138.2, 137.0, $134.5,134.5,131.4,131.1,130.3,129.7,129.4,128.9,127.2$, 126.9, 125.7, 124.7, 123.7, 122.8, 121.9, 121.3, 119.8, 119.1, 114.5, 46.5, 26.7. MS: $m / z 775\left[\mathrm{M}^{+}\right]$. Anal. Calc. for $\mathrm{C}_{55} \mathrm{H}_{41} \mathrm{~N}_{3} \mathrm{O}_{2}$ : C, 85.13; H, 5.33. Found: C, 84.92; H, 5.12. 
9,9-Dimethyl- $N$-(4-(6-(5-(5,5-dimethyl-1,3-dioxan-2-yl)thiophen-2-yl)-4-phenylquinolin-2-yl)phenyl)- $N$-(9,9-dimethyl-9H-fluoren-7-yl)-9H-fluoren-2-amine (5): A mixture of compound 3 (0.213 g, $0.28 \mathrm{mmol})$, 4,4,5,5-tetramethyl-2-(5(5,5-dimethyl-1,3-dioxan-2-yl)thiophen-2-yl)-1,3,2-dioxabo rolane $(0.11 \mathrm{~g}, 0.34 \mathrm{mmol}), 2 \mathrm{M}$ solution of $\mathrm{K}_{2} \mathrm{CO}_{3}(0.581 \mathrm{~g}$, $4.2 \mathrm{mmol})$ in $\mathrm{H}_{2} \mathrm{O}(2.1 \mathrm{~mL})$, and $\mathrm{Pd}\left(\mathrm{PPh}_{3}\right)_{4}(0.016 \mathrm{~g}, 0.014 \mathrm{mmol})$ in dry THF was refluxed at $80{ }^{\circ} \mathrm{C}$ for $24 \mathrm{~h}$. After cooling the solution, the organic layer was removed in vacuo. The crude product was extracted with $\mathrm{CH}_{2} \mathrm{Cl}_{2}$ and dried in $\mathrm{MgSO}_{4}$. The product 5 was obtained by silica gel column chromatography (eluent EA : $\mathrm{Hx}=1: 5) .{ }^{1} \mathrm{HNMR}\left(\mathrm{CDCl}_{3}\right) \delta 8.21(\mathrm{~d}, J=9.0 \mathrm{~Hz}$, $1 \mathrm{H}), 8.13(\mathrm{~d}, J=8.4 \mathrm{~Hz}, 1 \mathrm{H}), 8.08(\mathrm{~d}, J=1.5 \mathrm{~Hz}, 1 \mathrm{H}), 7.98(\mathrm{~d}$, $J=9.0 \mathrm{~Hz}, 1 \mathrm{H}), 7.81(\mathrm{~s}, 1 \mathrm{H}), 7.69-7.54(\mathrm{~m}, 9 \mathrm{H}), 7.41(\mathrm{~d}, J=$ $6.9 \mathrm{~Hz}, 2 \mathrm{H}), 7.36-7.23(\mathrm{~m}, 10 \mathrm{H}), 7.17(\mathrm{~d}, J=8.1 \mathrm{~Hz}, 2 \mathrm{H}), 7.11$ $(\mathrm{d}, J=3.6 \mathrm{~Hz}, 1 \mathrm{H}), 5.36(\mathrm{~s}, 1 \mathrm{H}), 3.72(\mathrm{~d}, J=11.1 \mathrm{~Hz}, 4 \mathrm{H}), 1.45$ $(\mathrm{s}, 12 \mathrm{H}), 1.30(\mathrm{~s}, 6 \mathrm{H}) .{ }^{13} \mathrm{C} \mathrm{NMR}\left(\mathrm{CDCl}_{3}\right) \delta 156.4,155.2,153.7$, 149.4, 149.1, 148.6, 147.1, 144.4, 141.3, 140.4, 139.0, 138.4, $137.7,134.7,133.1,132.1,129.6,128.9,128.6,128.0,127.1$, $126.7,126.3,125.9,123.7,123.4,122.6,122.0,120.8,119.8$, 119.6, 119.2, 98.4, 98.2, 77.6, 47.0, 30.4, 27.2, 23.0, 21.9. MS: $m / z 876\left[\mathrm{M}^{+}\right]$. Anal. Calc. for $\mathrm{C}_{61} \mathrm{H}_{52} \mathrm{~N}_{2} \mathrm{O}_{2} \mathrm{~S}: \mathrm{C}, 83.53 ; \mathrm{H}, 5.98$. Found: C, 83.32; H, 5.77.

5-(3-(4-(Bis(9,9-dimethyl-9H-fluoren-2-yl)amino)phenyl)4-phenylquinolin-6-yl)thiophene-2-carbaldehyde (6): To the compound 5 ( $0.174 \mathrm{~g}, 0.2 \mathrm{mmol})$ in THF was added water. Then trifluoroacetic acid (TFA, $1.075 \mathrm{~mL}$ ) was added to the solution. The mixture was refluxed for $2 \mathrm{~h}$. The solution was quenched with saturated aqueous sodium bicarbonate and extracted with $\mathrm{CH}_{2} \mathrm{Cl}_{2}$ and dried with $\mathrm{MgSO}_{4}$. The product 6 was obtained by silica gel column chromatography (eluent $\mathrm{EA}: \mathrm{Hx}=$ $1: 5) .{ }^{1} \mathrm{H} \mathrm{NMR}\left(\mathrm{CDCl}_{3}\right) \delta 9.89(\mathrm{~s}, 1 \mathrm{H}), 8.24(\mathrm{~d}, J=9.3 \mathrm{~Hz}, 1 \mathrm{H})$, $8.19(\mathrm{~s}, 1 \mathrm{H}), 8.13(\mathrm{~d}, J=8.1 \mathrm{~Hz}, 1 \mathrm{H}), 8.01(\mathrm{~d}, J=7.2 \mathrm{~Hz}, 1 \mathrm{H})$, $7.85(\mathrm{~s}, 1 \mathrm{H}), 7.74-7.59(\mathrm{~m}, 9 \mathrm{H}), 7.40(\mathrm{~d}, J=7.2 \mathrm{~Hz}, 4 \mathrm{H}), 7.33-$ $7.31(\mathrm{~m}, 9 \mathrm{H}), 7.17(\mathrm{~d}, J=7.8 \mathrm{~Hz}, 2 \mathrm{H}), 1.43(\mathrm{~s}, 12 \mathrm{H}) .{ }^{13} \mathrm{C} \mathrm{NMR}$ $\left(\mathrm{CDCl}_{3}\right) \delta 182.8,157.2,155.3,153.9,153.6,149.7,149.4,149.3$, $146.9,142.8,138.9,138.0,137.7,137.4,134.9,132.6,131.2$, $130.9,130.5,129.7,129.1,128.5,127.7,127.5,126.7,125.8$, $124.5,123.9,123.3,122.6,120.8,120.1,119.8,119.5,119.2$, 118.7, 47.0, 27.1. MS: $m / z 790\left[\mathrm{M}^{+}\right]$. Anal. Calc. for $\mathrm{C}_{56} \mathrm{H}_{42} \mathrm{~N}_{2} \mathrm{OS}$ : C, 85.03; H, 5.35; Found: C, 84.82; H, 5.14.

(Z)-3-(5-(3-(4-(Bis(9,9-dimethyl-9H-fluoren-2-yl)amino)phenyl)-4-phenylquinolin-6-yl)thiophen-2-yl)-2-cyanoacrylic acid (JK-129): A mixture of compound 6 (0.14 g, $0.2 \mathrm{mmol})$ and cyanoacetic acid $(0.034 \mathrm{~g}, 0.4 \mathrm{mmol})$ were added $\mathrm{CH}_{3} \mathrm{CN}$ $(30 \mathrm{~mL})$ and piperidine $(0.03 \mathrm{~g}, 0.35 \mathrm{mmol})$. The solution was refluxed for $6 \mathrm{~h}$. After cooling the solution, the organic layer was removed in vacuo. The crude product was extracted with $\mathrm{CH}_{2} \mathrm{Cl}_{2}$ and water. The pure product JK-129 was obtained by silica gel column chromatography (eluent $\mathrm{MC}: \mathrm{MeOH}=9: 1$ ). ${ }^{1} \mathrm{H}$ NMR (DMSO- $\left.d_{6}\right) \delta 8.32(\mathrm{~d}, J=8.7 \mathrm{~Hz}, 2 \mathrm{H}), 8.18(\mathrm{~s}, 1 \mathrm{H})$, $8.06(\mathrm{t}, J=8.1 \mathrm{~Hz}, 3 \mathrm{H}), 7.82-7.62(\mathrm{~m}, 12 \mathrm{H}), 7.52(\mathrm{~d}, J=6.9 \mathrm{~Hz}$, $2 \mathrm{H}), 7.37-7.28(\mathrm{~m}, 6 \mathrm{H}), 7.20(\mathrm{~d}, J=8.7 \mathrm{~Hz}, 2 \mathrm{H}), 7.12(\mathrm{~d}, J=$ $7.8 \mathrm{~Hz}, 2 \mathrm{H}), 1.40$ (s, 12H). ${ }^{13} \mathrm{C} \mathrm{NMR}$ (DMSO- $\left.d_{6}\right) \delta 164.2,163.0$, 155.6, 155.0, 153.9, 153.3, 149.1, 148.5, 148.2, 147.2, 146.3, $140.3,139.8,138.2,137.3,137.2,136.2,134.5,131.6,130.7$, $129.7,128.9,127.8,127.0,126.8,125.6,125.1$, 123.9, 123.6, $122.9,122.7,122.4,122.2,121.4,119.8,119.3,112.0,110.5$,
46.6, 26.8. MS: $m / z 857\left[\mathrm{M}^{+}\right]$. Anal. Calc. for $\mathrm{C}_{59} \mathrm{H}_{43} \mathrm{~N}_{3} \mathrm{O}_{2} \mathrm{~S}$ : C, 82.59; H, 5.05; Found: C, 82.38; H, 4.94.

9,9-Dimethyl- $\mathrm{N}$-(4-(6-(5-(5-(5,5-dimethyl-1,3-dioxan-2-yl)thiophen-2-yl)thiophen-2-yl)-4-phenylquinolin-2-yl)phenyl)$\mathrm{N}$-(9,9-dimethyl-9H-fluoren-7-yl)-9H-fluoren-2-amine (7): A mixture of compound 3 (0.233 g, $0.31 \mathrm{mmol})$, 4,4,5,5-tetramethyl-2-(5-(5-(5,5-dimethyl-1,3-dioxan-2-yl)thiophen-2-yl)thiophen-2-yl)-1,3,2-dioxaborolane (0.15 g, $0.37 \mathrm{mmol}), 2 \mathrm{M}$ solution of $\mathrm{K}_{2} \mathrm{CO}_{3}(0.638 \mathrm{~g}, 4.6 \mathrm{mmol})$ in $\mathrm{H}_{2} \mathrm{O}(2.3 \mathrm{~mL})$, and $\mathrm{Pd}\left(\mathrm{PPh}_{3}\right)_{4}(0.018 \mathrm{~g}, 0.015 \mathrm{mmol})$ in dry THF was refluxed at $80^{\circ} \mathrm{C}$ for $24 \mathrm{~h}$. After cooling the solution, the organic layer was removed in vacuo. The crude product was extracted with $\mathrm{CH}_{2} \mathrm{Cl}_{2}$ and dried in $\mathrm{MgSO}_{4}$. The product 5 was obtained by silica gel column chromatography (eluent EA : $\mathrm{Hx}=1: 3$ ). ${ }^{1} \mathrm{H} \mathrm{NMR}$ $\left(\mathrm{CDCl}_{3}\right) \delta 8.20(\mathrm{~d}, J=8.8 \mathrm{~Hz}, 1 \mathrm{H}), 8.12(\mathrm{~d}, J=8.7 \mathrm{~Hz}, 2 \mathrm{H}), 8.06$ $(\mathrm{d}, J=1.5 \mathrm{~Hz}, 1 \mathrm{H}), 7.90(\mathrm{~d}, J=8.8 \mathrm{~Hz}, 1 \mathrm{H}), 7.80(\mathrm{~s}, 1 \mathrm{H}), 7.68-$ $7.57(\mathrm{~m}, 8 \mathrm{H}), 7.40(\mathrm{~d}, J=7.8 \mathrm{~Hz}, 2 \mathrm{H}), 7.35-7.13(\mathrm{~m}, 13 \mathrm{H}), 7.05$ $(\mathrm{d}, J=10.5 \mathrm{~Hz}, 2 \mathrm{H}), 5.62(\mathrm{~s}, 1 \mathrm{H}), 3.70(\mathrm{~d}, J=11.1 \mathrm{~Hz}, 4 \mathrm{H})$, $1.44(\mathrm{~s}, 12 \mathrm{H}), 1.30(\mathrm{~s}, 6 \mathrm{H}) .{ }^{13} \mathrm{C} \mathrm{NMR}\left(\mathrm{CDCl}_{3}\right) \delta 156.4,155.2$, 153.7, 149.4, 149.0, 148.6, 147.0, 143.9, 140.4, 139.0, 138.3, $137.7,137.4,134.7,133.1,131.7,130.5,129.7,128.9,128.7$, $128.6,128.4,127.7,127.0,126.3,125.9,125.6,125.2$, 124.9, 124.5, 123.6, 123.0, 122.7, 122.5, 121.6, 120.8, 119.6, 119.2, 98.2, 77.4, 47.0, 30.4, 27.2, 23.1, 21.9. MS: $m / z 958$ [M $\mathrm{M}^{+}$. Anal. Calc. for $\mathrm{C}_{65} \mathrm{H}_{54} \mathrm{~N}_{2} \mathrm{O}_{2} \mathrm{~S}_{2}$ : C, 81.38; H, 5.67; Found: C, 81.17; H, 5.46 .

5'-(3-(4-(Bis(9,9-dimethyl-9H-fluoren-2-yl)amino)phenyl)4-phenylquinolin-6-yl)-2,2'-bithiophene-5-carbaldehyde (8): To the compound $7(0.208 \mathrm{~g}, 0.217 \mathrm{mmol})$ in THF was added water. Then TFA $(4.5 \mathrm{~mL})$ was added to the solution. The mixture was refluxed for $2 \mathrm{~h}$. The solution was quenched with saturated aqueous sodium bicarbonate and extracted with $\mathrm{CH}_{2} \mathrm{Cl}_{2}$ and dried with $\mathrm{MgSO}_{4}$. The product 8 was obtained by silica gel column chromatography (eluent $\mathrm{EA}: \mathrm{Hx}=1: 3$ ). ${ }^{1} \mathrm{H} \mathrm{NMR}$ $\left(\mathrm{CDCl}_{3}\right) \delta 8.22(\mathrm{~d}, J=8.7 \mathrm{~Hz}, 1 \mathrm{H}), 8.13(\mathrm{~d}, J=9.0 \mathrm{~Hz}, 1 \mathrm{H})$, $8.10(\mathrm{~d}, J=2.1 \mathrm{~Hz}, 1 \mathrm{H}), 7.97(\mathrm{~d}, J=9.0 \mathrm{~Hz}, 1 \mathrm{H}), 7.83(\mathrm{~s}, 1 \mathrm{H})$, 7.68-7.26 (m, 24H), $7.16(\mathrm{~d}, J=8.1 \mathrm{~Hz}, 2 \mathrm{H}), 1.44(\mathrm{~s}, 12 \mathrm{H})$. ${ }^{13} \mathrm{C} \mathrm{NMR}\left(\mathrm{CDCl}_{3}\right) \delta 182.6,174.5,156.8,155.3,153.7,149.6$, 149.1, 148.8, 147.1, 147.0, 145.9, 141.8, 139.0, 138.3, 137.5, $135.8,134.8,132.9,131.1,130.9,129.7,128.9,128.8,127.6$, $127.4,127.1,126.8,126.2,125.9,125.0,124.3,123.8,123.3$, 122.7, 122.2, 120.8, 119.9, 119.6, 119.3, 48.2, 27.2. MS: $\mathrm{m} / \mathrm{z}$ $872\left[\mathrm{M}^{+}\right]$. Anal. Calc. for $\mathrm{C}_{60} \mathrm{H}_{44} \mathrm{~N}_{2} \mathrm{OS}_{2}$ : C, 82.54; H, 5.08; Found: C, 82.32; H, 4.87.

(Z)-3-(5'-(3-(4-(Bis(9,9-dimethyl-9H-fluoren-2-yl)amino)phenyl)-4-phenylquinolin-6-yl)-2,2'-bithiophen-5-yl)-2-cyanoacrylic acid (JK-130): A mixture of compound 8(0.19 g, 0.21 $\mathrm{mmol})$ and cyanoacetic acid $(0.04 \mathrm{~g}, 0.42 \mathrm{mmol})$ were added $\mathrm{CH}_{3} \mathrm{CN}(30 \mathrm{~mL})$ and piperidine $(0.04 \mathrm{~g}, 0.57 \mathrm{mmol})$. The solution was refluxed for $6 \mathrm{~h}$. After cooling the solution, the organic layer was removed in vacuo. The crude product was extracted with $\mathrm{CH}_{2} \mathrm{Cl}_{2}$ and water. The pure product $\mathbf{J K - 1 3 0}$ was obtained by silica gel column chromatography (eluent $\mathrm{MC}: \mathrm{MeOH}=9$ : 1). ${ }^{1} \mathrm{H} \mathrm{NMR}$ (DMSO- $\left.d_{6}\right) \delta 8.30(\mathrm{~d}, J=7.8 \mathrm{~Hz}, 2 \mathrm{H}), 8.16(\mathrm{~s}, 1 \mathrm{H})$, $8.03(\mathrm{t}, J=10.2 \mathrm{~Hz}, 3 \mathrm{H}), 7.82-7.28(\mathrm{~m}, 22 \mathrm{H}), 7.20(\mathrm{~d}, J=8.1 \mathrm{~Hz}$, $2 \mathrm{H}), 7.10(\mathrm{~d}, J=7.8 \mathrm{~Hz}, 2 \mathrm{H}), 1.20(\mathrm{~s}, 12 \mathrm{H}) .{ }^{13} \mathrm{CNMR}$ (DMSO- $\left.d_{6}\right)$ $\delta 165.1,164.6,163.2,155.8,155.3,154.2,153.9,153.4,150.1$, $148.7,148.4,147.4,146.5,140.5,140.0,138.4,137.5,137.4$, 
$136.8,136.4,134.9,134.7,131.8,130.9,129.9,128.9,128.0$, $127.2,127.0,125.8,125.3,124.1,123.8,123.1,122.9,122.6$, $122.4,121.6,120.0,119.5,112.5,110.7,46.7,26.9$. MS: $\mathrm{m} / z$ $939\left[\mathrm{M}^{+}\right]$. Anal. Calc. for $\mathrm{C}_{63} \mathrm{H}_{45} \mathrm{~N}_{3} \mathrm{O}_{2} \mathrm{~S}_{2}$ : C, 80.48; H, 4.82; Found: C, 80.27; H, 4.61.

Acknowledgments. We are grateful to the Korea University Researh Program (2009).

\section{References}

1. Robertson, N. Angew. Chem. Int. Ed. 2006, 45, 2338.

2. (a) O'Regan, B.; Grätzel, M. Nature 1991, 353, 737. (b) Grätzel, M. Nature 2001, 414, 338.

3. (a) Chiba, Y.; Islam, A.; Watanabe, Y.; Komiya, R.; Koide, N.; Han, L. Jpn. J. Appl. Phys. Part 2 2006, 45, L638. (b) Nazeeruddin, M. K.; De Angelis, F.; Fantacci, S.; Selloni, A.; Viscardi, G.; Liska, P.; Ito, S.; Takeru, B.; Grätzel, M. J. Am. Chem. Soc. 2005, 127, 16835. (c) Cao, Y.; Bai, Y.; Yu, Q,; Cheng, Y.; Liu, S.; Shi, D.; Gao, F.; Wang, P. J. Phys. Chem. C 2009, 113, 6290. (d) Gao, F.; Wang, Y.; Shi, D.; Zhang, J.; Wang, M.; Jing, X.; Humphry-Baker, R.; Wang, P.; Zakeeruddin, S. M.; Grätzel, M. J. Am. Chem. Soc. 2008, 130, 10720.

4. (a) Ito, S.; Miura, H.; Uchida, S.; Takata, M.; Sumioka, K.; Liska, P.; Comte, P.; Péchy, P.; Grätzel, M. Chem. Commun. 2008, 5194. (b) Horiuchi, T.; Miura, H.; Sumioka, K.; Uchida, S. J. Am. Chem. Soc. 2004, 126, 12218 .

5. (a) Zhang, G.; Bala, H.; Cheng, Y.; Shi, D.; Lv, X.; Yu, Q.; Wang, P. Chem.Commun. 2009, 2198. (b) Choi, H.; Baik, C.; Kang, S. O.; Ko, J.; Kang, M.-S.; Nazeeruddin, M. K.; Grätzel, M. Angew. Chem. Int. Ed. 2008, 47, 327. (c) Xu, M.; Wenger, S.; Bala, H.; Shi, D.; Li, R.; Zhou, T.; Zakeeruddin, S. M.; Grätzel, M.; Wang, P. J. Phys. Chem. C 2009, 113, 2966. (d) Kim, S.; Kim, D.; Choi, H.; Kang, M.-S.; Song, K.; Kang, S. O.; Ko, J. Chem. Commun. 2008, 4951. (e) Wang, Z.-S.; Koumura, N.; Cui, Y.; Takahashi, M.; Sekiguchi, H.; Mori, A.; Kubo, T.; Furube, A.; Hara, K. Chem. Mater. 2008, 20, 3993. (f) Kim, S.; Lee, J. K.; Kang, S. O.; Ko, J.; Yum, J.-H.; Fantacci, S.; De Angelis, F.; Di Censo, D.; Nazeeruddin, M. K.; Grätzel, M. J. Am. Chem. Soc. 2006, 128, 16701.

6. (a) Hara, K.; Kurashige, M.; Dan-oh, Y.; Kasada, C.; Shinpo, A.; Suga, S.; Sayama, K.; Arakawa, H. New. J. Chem. 2003, 27, 783. (b) Hara, K.; Miyamoto, K.; Abe, Y.; Yanagida, M. J. Phys. Chem. B 2005, 109, 23776

7. (a) Li, S.-L.; Jiang, K.-J.; Shao, K.-F.; Yang, L.-M. Chem. Commun.
2006, 2792. (b) Wang, M.; Xu, M.; Shi, D.; Li, R.; Gao, F.; Zhang, G.; Yi, Z.; Humphry-Baker, R.; Wang, P.; Zakeeruddin, S. M.; Grätzel, M. Adv. Mater. 2008, $20,4460$.

8. (a) Liu, W.-H.; Wu, I.-C.; Lai, C.-H.; Chou, P.-T.; Li, Y.-T.; Chen, C.-L.; Hsu, Y.-Y.; Chi, Y. Chem. Commun. 2008, 5152. (b) Choi, H.; Lee, J. K.; Song, K. H.; Song, K.; Kang, S. O.; Ko, J. Tetrahedron 2007, 63, 1553. (c) Xu, M.; Wenger, S.; Bala, H.; Shi, D.; Li, R.; Zhou, Y.; Zakeeruddin, S. M.; Grätzel, M.; Wang, P. J. Phys. Chem. C 2009, 113, 2966.

9. (a) Kim, J.-J.; Choi, H.; Lee, J.-W.; Kang, M.-S.; Song, K.; Kang, S. O.; Ko, J. J. Mater. Chem. 2008, 18, 5223. (b) Velusamy, M.; Justin Thomas, K. R.; Lin, J. T.; Hsu, Y.-C.; Ho, K.-C. Org. Lett. 2005, 7, 1899.

10. Kim C.; Choi, H.; Kim, S.; Baik, C.; Song, K.; Kang, M.-S.; Kang, S. O.; Ko, J. J. Org. Chem. 2008, 73, 7072.

11. Cui, Y.; Zhang, X.; Jenekhe, S. A. Macromolecules 1999, 32, 3824.

12. Peng, Z. H.; Bao, Z. N.; Galvin, M. E. Adv. Mater. 1998, 10, 680.

13. Zhang, X.; Kale, D. M.; Jenekhe, S. A. Macromolecules 2002 , 35,382 .

14. (a) Tonzola, C. J.; Alam, M. M.; Bean, B. A.; Jenekhe, S. A. Macromolecules 2004, 37, 3554. (b) Tonzola, C. J.; Alam, M. M.; Jenekhe, S. A. Adv. Mater. 2002, 14, 1086.

15. Agrawal, A. K.; Jenekhe, S. A. Chem. Mater. 1992, 4, 95.

16. Zhang, X.; Gorohmaru, H.; Kadowaki, M.; Kobayashi, T.; Ishi-I, T.; Thiemann, T.; Mataka, S. J. Mater. Chem. 2004, 14, 1901.

17. (a) Sayama, K.; Hara, K.; Mori, N.; Satsuki, M.; Suga, S.; Tsukagoshi, S.; Abe, Y.; Sugiharh, H.; Arakawa, H. Chem. Commun. 2000, 1173. (b) Sayama, K.; Tsukagoshi, S.; Hara, K.; Ohga, Y.; Shinpou, A.; Abe, Y.; Suga, S.; Arakawa, H. J. Phys. Chem. B 2002, $106,1363$.

18. (a) Wang, P.; Zakeeruddin, S. M.; Moser, J.-E.; Grätzelm M. J. Phys. Chem. B 2003, 107, 13280. (b) Bond, A. M.; Deacon, G. B.; Howitt, J.; MacFarlane, D. R.; Spiccia, L.; Wolfbauer, G. J. Electrochem. Soc. 1999, 146, 648.

19. Atechian, S.; Nock, N.; Norcross, R. D.; Ratni, H.; Thomas, A. W.; Verron, J.; Masciadri, R. Tetrahedron 2007, 63, 2811.

20. Nakade, S.; Kanzaki, T.; Wada, Y.; Yanagida, S. Langmuir 2005, $21,10803$.

21. Kang, M.-S.; Ahn, K.-S.; Lee, J.-W.; Kang, Y. S. J. Photochem. Photobiol. A: Chem. 2008, 195, 198.

22. Ahn, K.-S.; Kang, M.-S.; Lee, J.-K.; Shin, B.-C.; Lee, J.-W. Appl. Phys. Lett. 2006, 89, 013103.

23. Ahn, K.-S.; Kang, M.-S.; Lee, J.-W.; Kang, Y. S. J. Appl. Phys. 2007, 101, 084312.

24. Hara, K.; Miyamoto, K.; Abe, Y.; Yanagida, M. J. Phys. Chem. B $\mathbf{2 0 0 5}, 109,23776$ 